\title{
Ristiriitaista ja epämääräistä tasa-arvoa
}

Edistys ei aina edisty. Tältä näyttää, kun lukee aikuiskoulutuksen johtoryhmän toimesta julkaistuja muistioita. Vaikka Tapio Vahervan aikuiskoulutuksen ihmiskuvasta laatiman selvityksen perusteista saattoi olla radikaalisti eri mieltä, oli muistio sentään tehty tiedemiehen rutiinilla ja joltisellakin loogisella eleganssilla. Samaa ei voi sanoa johtoryhmän uusimmasta muistiosta "Tasa-arvo aikuiskoulutuksen suunnittelun periaatteena".

Johdonmukaisuus on kaiken järkevän kes- kustelun lähtökohta: logiikan alkeistotuuden mukaan ristiriitaisesta lauseesta voidaan päätellä mitä tahansa, esimerkiksi kaksi toisensa poissulkevaa lausetta, mikä johtaa ajatukselliseen anarkiaan. Tasa-arvomuistiossa esiintyy kahdenlaisia ristiriitoja: ensinnäkin julkilausuttujen ajatusten välisiä ristiriitoja ja toiseksi julkilausuttujen ajatusten ja tosiasiallisten lähtökohtien välisiä ristiriitoja.

Muistion kieli on perin kiemuraista. En kuulu niihin ihmisiin, jotka periaatteessa karsasta- 
vat vieras- ja tieteellisperäistä terminologiaa ja monimutkaisia virkkeitä. Kielen on oltava riittävän erottelukykyistä suhteessa tarkastelukulmaan. Tasa-arvopaperissa ilmenee kuitenkin kielellistä koristelua, terminologista pursotusta ja rakenteellista epäselvyyttä. Esimerkistä käynee seuraava virke:

"Koulutussuunnittelun lähtökohtana on syytă ottaa huomioon, ettei deprivoituneiden ihmisten tai ryhmien koulutuksellisia ongelmia voida ratkaista pelkästään koulutuspoliittisin toimenpitein, vaan ne edellyttävät yhteiskuntapolitiikan eri sektoreiden kiinteää ja jatkuvaa yhteistyötä sekä sellaisia koulutuksellisia ja sivistyksellisiä järjestelyjä, jotka vastaavat aikuisen elämäntilanteen konkreettisiin oppimistilanteisiin."

Kieli, josta nykyisin tietääkseni myös valtiohallinnossa pyritään pois, näyttää nousseen muistion tyylilliseksi ihanteeksi. Tietysti tällaisella kielellä on myös hyvät puolensa: sen poimuista on yhtä vaikea havaita ajatus kuin sen puuttuminenkin.

\section{Kaksi vaihtoehtoa}

Muistion ajatuksellisena lähtökohtana on kaksi mahdollisuutta ymmärtää tasa-arvoa aikuiskoulutuksessa: hieman pelkistäen sanottuna nämä vaihtoehdot ovat lähteminen yhteiskunnan tai lähteminen yksilön arvomaailmasta. Ilmeisesti kritiikki, jossa johtoryhmän aiempia muistioita on arvosteltu ihmisen unohtamisesta, byrokraattisuudesta ja teknokraattisuudesta, on vaikuttanut: muistiossa on valittu yksilökeskeinen lähtökohta tasa-arvon hahmottelussa.

Kuitenkin synnintunto ilmenee väärässä asiassa. Niin yhteiskuntatieteiden kuin terveen lautamiesjärjenkin mukaan tasa-arvo on tyypillisesti yhteiskunnallinen ilmiö: se ei koske yksilöitä sinänsä, vaan yksilöiden välisiä sosiaalisia suhteita. Muistiossa tehty ratkaisu on nähdäkseni virheellinen.

Ilmeisesti johtoryhmällä on kuitenkin ollut aivan hyvä pyrkimys, mutta ajattelun hämäryys on johtanut loogiseen kömmähdykseen. Luulen, että johtoryhmä on yrittänyt sanoa yksilöiden olevan varsin erilaisia ja esittää tämän erilaisuuden kunnioittamista.

Näin pitkälle kaikki on hyvin. Jos kuitenkin yksilöiden välisen erilaisuuden kunnioittami'sen ymmärretään merkitsevän sitä, että lähtökohtana on yksilön arvomaailma, on kömmähdys väistämätön. Se, muuttuuko erilaisuus eriarvoisuudeksi, on tyypillisesti yhteiskuntaan liittyvä piirre. Tämä on myös tasa-arvopolitii- kan ydinkysymys kaikilla sosiaalisen elämän alueilla.

Vaikka en halua olla pikkumainen, en kuitenkaan voi olla huomauttamatta sinänsä mitättömän tuntuisesta mutta periaatteellisesti laajakantoisesta käsitesekaannuksesta: lähtökohtavaihtoehtoja hahmoteltaessa muistiossa samaistetaan ihminen ja yksilö. Yksilöllä tarkoitetaan johonkin ryhmään, lajiin tai muuhun kokonaisuuteen kuuluvaa individia; ihminen siis viittaa lajiin, johon yksilö kuuluu. Jos lähtökohtana olisi ollut ihminen, koko problematiikka olisi jäsentynyt varsin eri tavoin kuin nyt.

Muistion epäjohdonmukaisuus näkyy jatkossa mm. siten, että julkilausutusta yksilökeskeisestä lähtökohdasta luovutaan välittömästi, kun tasa-arvoa ryhdytään lähemmin kehittelemään. Harppaus ei tapahdu tasa-arvon käsitteen yhteiskunnalliseen vaan suorastaan totalitaristiseen tulkintaan.

\section{Julkilausumaton kuperkeikka}

Muistiossa arvostellaan tähänastisia tasa-arvopyrkimyksiä - tosin niitä sen kummemmin dokumentoimatta ja yksilöimättä - ulkokohtaisuudesta ja yhteiskunnallisesta näkökulmasta. Omana - hedelmällisempänä - vaihtoehtonaan muistio esittelee tasa-arvopyrkimysten sitomisen "yksilön omiin potentiaalisiin mahdollisuuksiin sekä hänen omaksumaansa arvomaailmaan". Tästä pitäisikin sitten jo seurata "osallistujien ehdoilla" toteutettava koulutuspolitiikka.

Jokseenkin välittömästi kuitenkin ilmenee, mitä näillä julkilausutuilla "osallistujien ehdoilla" tosiasiallisesti tarkoitetaan: muistion mukaan ihmisten ja ryhmien "on havaittava oma tilansa", heidän on oivallettava myönteistä muutosta sisältävät mahdollisuudet, joihin heiltä on mennyt usko", jos joltakin puuttuu halu osallistua koulutukseen, "'on se hänessä herätettävä koulutus- ja muun yhteiskuntapolitiikan keinoin".

Näin siis tehdään täydellinen kuperkeikka. Yksilön potentiaalisten mahdollisuuksien sijaan astuvat valtion resurssit ja yksilön arvomaailman sijaan johtoryhmän arvomaailma. Julistetusta subjektista, yksilöstä, tehdään objekti, jolle johtoryhmä alkaa esittää omia vaatimuksiaan.

Tämän looginen seuraus näkyykin sitten johtopäätöksissä: "deprivoituneen tai muutoin passiivisen ihmisen maailma ei ole 'hallinnon- 
aloittain järjestyksessä' ', Ihmisestä tulee siis objekti, jonka tajuntaa järjestetään hallinnonaloittain.

Kuperkeikan takana on ilmeisesti se arkikokemukseen perustuva realistinen olettamus, että on varsin suuri joukko yksilöitä, joiden arvojärjestelmässä ei koulutuksella ole sijaa. Jos johtoryhmä ottaisi tämän lähtökohdaksi, voisi se lopettaa työnsä välittömästi. Koska tämä ei ole mahdollista, täytyy nämä ihmiset uudelleenkasvattaa. Niinpä sitten päädytäänkin tulkitsemaan näiden ihmisten puolesta, millainen heidän yksilöllinen arvojärjestelmänsä tulisi koulutuksen osalta olla. Tämä sitten jo sisältääkin vaarallisen totalitarismin siemenen.

Muistiossa luovutaan myös toisellakin tavalla yksilökeskeisestä lähtökohdasta. Tasa-arvopolitiikan kohteet määritellään ryhminä. Ihmiset eivät kuitenkaan jakaannu yksilöiksi vaan demografisiksi väestöryhmiksi iän, sukupuolen, koulutuksen ja muiden vastaavien tekijöiden perusteella. Koska tällaisten ryhmien ominaisuudet poikkeavat yksilöiden ominaisuuksista, eivät näihin ryhmiin kohdistuvat toimenpiteet voi ottaa huomioon yksilökeskeistä lähtökohtaa.

Mitä siis jää käteen yksilökeskeisestä lähtökohdasta? Olisi väärin sanoa, ettei mitään. Todellisuudessa sanojen takaa paljastuvat hyvinkin totunnaiset tasa-arvopolitiikan perusolettamukset valtiollistuneessa muodossa.

\section{Käsittämätön peruskäsite}

Tasa-arvokäsitteen merkityssisältö jää avautumatta. Jo muistion alkupuolella todetaan, että siinä "'ei esitetä suosituksena koulutuksellisen tasa-arvon määritelmää, mutta pyritään antamaan aineksia sen myöhemmin tapahtuvaa muotoamista varten"'. Todellakin: muistiossa ei esitetä koulutuksellisen eikä minkään muunkaan tasa-arvon määritelmää, ei suosituksena eikä muutenkaan.
Johtoryhmä on kuitenkin ollut peloton. Huolimatta näin hatarasta pohjasta, se on uskonut pystyvänsä esittämään "'tasa-arvopolitiikan yleisiä lähtökohtia", luonnehtimaan "tasa-arvoa lisäävän koulutuspolitiikan tunnuspiirteitä" ja ehdottelemaan "tasa-arvoa lisäävien toimenpiteiden kohdentamista".

Kysymys on kuitenkin hiekalle rakentamisesta. Tosiasiassa jää auki, minkä politiikan yleisistä lähtökohdista, mitä lisäävän koulutuspolitiikan tunnuspiirteistä ja mitä lisäävien toimenpiteiden kohdentamisesta on kyse.

\section{Muistion anti?}

Muistiossa on käytetty vanhaa tuttua jakoa aikuiskoulutuksen osa-alueisiin, siis yleissivistävään, ammatilliseen, yhteiskunnalliseen ja harrastusopintoihin. Tämä jako nähdään edelleenkin niin ongelmattomana, ettei vaivauduta edes mainitsemaan esille nousseista probleemeista.

Muistiossa viittaillaan laajoihin kansainvälisiin vertaileviin aineistoihin ja niiden tuloksiin, edes mainitsematta mistä aineistoista on kyse. Edelleen johtoryhmä hahmottelee aikuisuuden luonnetta viittaamatta ainoaankaan tutkimukseen. Yhteiskunnan ja tasa-arvon välistä kytkentää koskevat perustavat pohdiskelut on korvattu muutamalla hajanaisella ja pinnallisella trivaliteetilla.

En tunne, millaisen työprosessin tuloksena tasa-arvomuistio on syntynyt. Mutta jos johtoryhmä on panostanut siihen merkittävästi resurssejaan, niin näen tilanteen synkkänä enkä voi nähdä kehittämisorganisaatiolla olevan olennaisesti myönteistä annettavaa ainakaan vapaalle sivistystyölle. 